\title{
BUDAYA ORGANISASI SEKOLAH DAN MOTIVASI BERPRESTASI DENGAN KINERJA GURU PADA SEKOLAH DASAR NEGERI GUGUS ADIARSA KARAWANG BARAT
}

\author{
Isnaeni Wuryantina \\ Guru Sekolah Dasar Adiarsa Karawang \\ Isnaeni@gmail.com
}

\begin{abstract}
The objective of this research is to obtain information the correlation between of organization culture school and achievement motivation with performance of the teacher elementary school cluster Adiarsa in distric of West Karawang. The approach used was quantitative by survey method in elementary school cluster Karangpawitan in distric of West Karawang. The sample collect from 40 teacher of elementary school who obtained with random technique, through an instrument that has been validated a questionnaire using scale likert 1-5. Then the data were analyzed by using regression. The research findings are: (1) there is correlation organization culture school with performance; (2) there is correlation achievement motivation with performance; (3) there is correlation organization culture school and achievement motivation with performance. The result of the research implied that in the organization culture school, the achievement motivation, the quality of Performance.
\end{abstract}

Keywords: organization culture school, achievement motivation, performance

Abstrak: Tujuan dari penelitian ini adalah untuk mendapatkan informasi korelasi antara sekolah budaya organisasi dan motivasi berprestasi dengan kinerja Adiarsa gugus guru sekolah dasar di kecamatan dari Karawang Barat. Pendekatan yang digunakan adalah kuantitatif dengan metode survey di SD gugus sekolah Karangpawitan di distric dari Karawang Barat. Sampel mengumpulkan dari 40 guru sekolah dasar yang diperoleh dengan teknik random, melalui instrumen yang telah divalidasi kuesioner menggunakan skala Likert 1-5. Kemudian data dianalisis dengan menggunakan regresi. Temuan penelitian adalah: (1) ada sekolah budaya organisasi korelasi dengan kinerja; (2) ada motivasi berprestasi korelasi dengan kinerja; (3) ada sekolah budaya organisasi korelasi dan motivasi berprestasi dengan kinerja. Hasil penelitian yang tersirat bahwa di sekolah budaya organisasi, motivasi berprestasi, kualitas kinerja.

Kata kunci: sekolah budaya organisasi, motivasi berprestasi, kinerja

Menumbuhkan potensi anak didik di sekolah dasar secara optimal diperlukan guru yang profesional. Guru yang profesional adalah guru yang memiliki seperangkat kemampuaan antara lain menguasai materi pelajaran secara tuntas, mampu memilih dan menerapkan metode pembelajaran yang tepat dan dapat memotivasi peserta didik.
Salah satu fungsi pendidikan di sekolah dasar adalah menumbuhkan potensi anak didik melalui bimbingan guru-guru yang profesional dan yang bekerja secara optimal. Dengan kata lain diperlukan kinerja guru yang baik untuk menumbuhkan potensi peserta didik agar tercapai tujuan pendidikan dasar. 
Budaya Organisasi Sekolah dan Motivasi Berprestasi Isnaeni Wuryantini

Untuk meningkatkan kinerja guru agar mampu bekerja secara profesional Pemerintah telah melakukan berbagai pelatihan atau penataran para guru. Namun umumnya pembelajaran dilakukan dalam bentuk satu arah, guru lebih banyak ceramah di hadapan siswa. Guru beranggapan tugasnya hanya mentransfer pengetahuan yang dimilikinya dengan target tersampaikannya topik-topik yang tertulis dalam kurikulum. Pada umumnya guru-guru tidak memberi inspirasi kepada siswa untuk berkreasi dan tidak melatih siswa untuk mandiri sehingga pelajarannya kurang menantang siswa untuk berpikir. Akibatnya siswa tidak menyenangi pelajaran.

Dalam rangka melaksanakan, mengelola, mengurus dan mengatur diperlukan manajemen yaitu proses memimpin, membimbing, menyiapkan fasilitas kepada bawahan supaya bekerja sama untuk mencapai tujuan bersama. Demikian juga, di dalam suatu organisasi pendidikan apabila dicermati serta diamati akan terjadi proses interaksi kerja sama antara pemimpin dengan bawahan yang diperhatikan, diarahkan, dibina dan dikembangkan tetapi kemungkinan juga dipaksakan, agar perilaku tersebut sesuai dengan harapan pemimpin di dalam suatu lembaga.
Motivasi sebagai proses psikologis timbul diakibatkan oleh faktor di dalam diri seseorang itu sendiri yang disebut intrinsik dan faktor di luar diri seseorang disebut faktor ekstrinsik. Faktor di dalam diri seseorang dapat berupa kepribadian, sikap, pengalaman dan pendidikan atau berbagai harapan, cita-cita yang menjangkau masa depan. Sedangkan faktor di luar diri dapat ditimbulkan oleh berbagai sumber, bisa karena pengaruh pemimpin, kolega atau faktor-faktor lain yang sangat kompleks.

Sekolah juga merupakan bentuk keorganisasian moral, berbeda dengan bentuk keorganisasian lain yang berorientasi kepada keuntungan. Hal itu membawa konsekwensi logis bagi setiap komponen sekolah unruk bersinergi, memiliki komitmen yang sama dan menerapkan norma dan nilai yang dianut sekolah demi tercapainya tujuan pendidikan sekolah.

Organisasi sekolah lebih menekankan kepada output pendidikan yang berkualitas sedangkan organisasi lain penekanannya pada keuntungan yang sebesar-besarnya. Output pendidikan yang berkualitas dapat dicapai apabila sekolah berjalan efektif. Sekolah yang berjalan efektif apabila fungsi-fungsi manajemen (perencanaan, pengorganisasian, pengarahan dan pengawasan) berfungsi dengan baik 
serta unsur-unsur penunjang tersedia dan memenuhi persyaratan. Salah satu unsur penting mendukung jalannya sekolah adalah sumber daya manusia (kepala sekolah, guru dan staf administrasi) yang mempunyai peran penting dalam menentukan keberhasilan sekolah untuk mencapai tujuan.

Hasil pengamatan di lapangan khususnya pada Sekolah Dasar (SD) baik Negeri maupun Swasta di Kabupaten Karawang Jawa Barat bahwa kinerja guru dikatagorikan cukup baik walaupun belum menunjukkan keberhasilan yang signifikan seperti yang diharapkan oleh pemerintah karena kemungkinan kurangnya pemahaman, pelatihan, dan penerapan tentang kinerja guru yang sesuai dengan tugas pokok dan fungsi dari guru tersebut.

Kinerja guru Sekolah Dasar Negeri di Kabupaten Karawang masih perlu dioptimalkan, banyak faktor yang menyebabkan diantaranya adalah kurang kondusifnya budaya organisasi di sekolah, rendahnya kepuasan kerja yang dimiliki, motivasi berprestasi yang masih rendah, rendahnya komitmen organisasi, motivasi kerja masih rendah, lingkungan, sistem pembagian insentif, sarana-prasarana, hubungan interpersonal, komunikasi antar pribadi guru dengan guru, guru dengan kepala sekolah, guru dengan murid perlu ditingkatkan.

Kinerja guru ini berhubungan dengan faktor internal maupun faktor eksternal. Faktor internal ini antara lain berupa motivasi berprestasi, disiplin kerja dan sikap terhadap profesi. Sedangkan faktor eksternal seperti supervisi kepala sekolah, budaya organisasi sekolah, kepemimpinan kepala sekolah dan iklim sekolah.

Masalah yang terjadi di lapangan kami tertarik untuk menganalisa dan mencoba penelitian korelasi antara budaya organisasi dan motivasi berprestasi dengan kinerja guru SD.

Berdasarkan uraian di atas dapat dikemukakan perumusan masalah sebagai berikut: 1) Apakah terdapat hubungan antara budaya organisasi dengan kinerja guru SD? 2) Apakah terdapat hubungan antara motivasi berprestasi dengan kinerja guru SD? 3) Apakah terdapat hubungan antara budaya organisasi dan motivasi berprestasi secara bersama-sama dengan kinerja guru SD?

Kinerja merupakan penampilan kerja seseorang. Kinerja merujuk pada kuantitas dan kualitas penyeselaian pekerjaan. Sebagaimana di ungkapkan Colquitt, Lepine dan Wetson (2009 : 37) berpendapat bahwa kinerja secara formal didefinisikan sebagai 
Budaya Organisasi Sekolah dan Motivasi Berprestasi Isnaeni Wuryantini

nilai yang telah diperlihatkan oleh perilaku anggota yang berkontribusi baik secara positif atau negatif untuk pencapaian tujuan organisasi.

Robbins (2003:410) menyatakan bahwa kinerja merupakan hasil evaluasi terhadap pekerjaan yang dilakukan dibandingkan dengan kriteria yang telah ditetapkan. Oleh karena itu, peningkatan atau penurunan kinerja seseorang dapat diketahui dengan adanya pedoman atau standar kerja yang telah ditetapkan.

Berbicara tentang hakekat kinerja, Patricia King (1993:19) berpendapat bahwa kinerja merupakan aktivitas seseorang dalam melaksanakan tugas pokok yang dibebankan kepadanya. Luthans (2008:240) dengan pendekatan behavioral menyatakan dalam manajemen kinerja adalah kuantitas atau kualitas sesuatu yang dihasilkan atau jasa yang diberikan oleh seseorang yang melakukan pekerjaan. Mengacu pada batasan tersebut dapat dinyatakan bahwa kinerja adalah hasil, baik kuantitas maupun kualitas yang dicapai seseorang dalam melaksanakan tugas-tugas yang menjadi tanggung jawabnya.

Newstrom dan Davis (2002:132) menyatakan, kinerja yang baik akan dihasilkan oleh pegawai atau karyawan yang puas dalam organisasi. Pegawai atau karyawan yang merasa puas akan melakukan upaya-upaya yang mendukung untuk dapat melakukan pekerjaan dengan baik. Dalam konteks tersebut, jelas terkandung makna bahwa kinerja sangat berkaitan dengan kepuasan kerja seseorang, sehingga jika seseorang atau kepala sekolah pada suatu organisasi terpuaskan dengan pekerjaannya, kesejahteraan yang diberikan oleh organisasi, dan produknya dipergunakan oleh orang banyak serta mendapat pujian dari pimpinannya, maka akan menghasilkan kinerja yang maksimal.

Dengan demikian, kinerja adalah hasil unjuk kemampuan dari seseorang dalam menyelesaikan tugas-tugas yang menjadi wewenang dan tanggung jawab dengan indikator: 1) pemahaman tugas; 2) melaksanakan tugas; 3) bekerja sesuai dengan waktu kerja; 4) penilaian terhadap kualitas kerja; 5) menciptakan suasana kerja kondusif; dan 6) ko-munikasi dengan rekan sekerja untuk mencapai tujuan organisasi.

Budaya organisasi tidak muncul begitu saja dari kehampaan dan setelah terbentuk, jarang budaya itu berangsur padam. Para pendiri organisasi biasanya mempunyai dampak besar pada budaya awal organisasi. Mereka mempunyai visi mengenai bagaimana seharusnya organisasi itu. 
Proses penciptaan budaya organisasi terjadi dalam 3 cara, yaitu Pertama, para pendiri hanya mempekerjakan dan mempertahankan anggota atau karyawan yang sepikiran dan seperasaan dengan mereka. Kedua, pendiri melakukan indoktrinasi dan sosialisasi tentang cara berpikir dan perilaku mereka kepada anggota atau karyawan. Ketiga, perilaku pendiri sendiri bertindak sebagai model peran yang mendorong karyawan untuk mengidentifikasikan keyakinan, nilai dan asumsi pendiri tersebut.

Robbins dan Judge (2007:511) menyatakan organizational culture is a system of shared meaning held by members that distinguishes the organization from other organizations. Budaya organisasi merupakan sistem berbagai nilai yang dilakukan oleh para anggota organisasi yang membedakan organisasi tersebut dengan organisasi lain.

McShane dan Von Glinov (2008:461) tentang budaya organisasi adalah sebagai berikut: The basic pattern of shared values and assumptions governing the way employees within an organization think about and act on problems an opportunities.

Pendapat Gibson, Ivancevich, Donnelly dan Konopaske mengatakan bahwa budaya organisasi sebuah konsep yang penting, budaya organisasi sebagai persfektif untuk memahami perilakuperilaku individu dan kelompok dalam suatu organisasi, memiliki keterbatasan. Pertama, budaya bukan satu-satunya cara untuk berorganisasi. Kita sudah membahas pemandangan sistem yang tidak menyinggung budaya. Kedua, seperti banyak konsep lain budaya organisasi belum tentu didefinisikan sama oleh dua ahli teori dan peneliti. Beberapa definisi budaya adalah: (1) simbol, bahasa, ideologi, dan mitos; (2) naskah organisasi yang diambil dari naskah pribadi pendiri organisasi atau pemimpin yang dominan; (3) merupakan sebuah produk, sebuah sejarah didasarkan pada simbol dan merupakan suatu abstraksi dari perilaku dan produk perilaku.

Sebagaimana yang disampaikan oleh Stephen Stolp tentang School Culture, dari beberapa hasil studi menunjukkan bahwa budaya organisasi di sekolah berkolerasi dengan peningkatan motivasi dan prestasi belajar siswa serta kepuasan kerja dan produktivitas guru. Sesuai dengan studi yang dilakukan oleh Leslie J. Fyans, Jr. dan Martin L. Machr tentang pengaruh dari lima dimensi budaya organisasi di sekolah yaitu : tantangan akademik, prestasi komperatif, penghargaan terhadap prestasi, komunitas sekolah dan persepsi tentang tujuan sekolah. 
Budaya Organisasi Sekolah dan Motivasi Berprestasi Isnaeni Wuryantini

Bagian yang terpenting dari suatu budaya organisasi adalah kultur dan nilai nilai yang dikembangkan oleh sebuah organisasi harus mencerminkan kemampuan organisasi tersebut dalam beradaptasi dengan ligkungannya. Nilai - nilai itu bukan sekedar dicatat dan dipajang diruang - ruang kerja, melainkan ditanam dan diberi pupuk. Nilai-nilai yang ditanam kepada semua anggota organisasa tersebut lambat laun akan berubah menjadi kebiasaan contohnya dengan kegiatan-kegiatan, ritual-ritual (pengangkatan, promosi, dan pelepasan) dan simbol-simbol (bahasa, pakaian, logo, tulisan, benda-benda), serta bukti nyata (penegakan displin, pemberian penghargaan, kegiatan sosial, dan lain-lain).

Senada dengan Kasali, Robbins dalam bukunya juga memaparkan bagaimana nilai-nilai diterima oleh anggota organisasi. Budaya diteruskan kepada anggota organisasi dengan cara beragam. Namun cara yang paling ampuh menurut Robbins adalah melalui cerita, ritual, lambang materi, dan bahasa.

Dapat disimpulkan bahwa budaya organisasi adalah suatu sistem makna yang dapat dipersepsikan dan diterapkan dalam organisasi untuk mempengaruhi pola berpikir, sikap dan perilaku para anggota organisasi dengan indikator yaitu inovasi dan pengambilan resiko; perhatian terhadap detail; orientasi tim; keagresifan; dan kemantapan.

Steer dan Porter (1991:5) mengatakan motivasi berasal dari kata "movere" dalam bahasa latin yang berarti "to move", bergerak atau dorongan bagi seseorang untuk berbuat; atau ide pokok yang berpengaruh besar terhadap tingkah laku manusia. Menurut Moskowits dalam Hasibuan (2007:96), motivasi didefinisikan secara umum sebagai inisiatif dan pengarahan tingkah laku, dan pelajaran motivasi merupakan pelajaran tingkah laku.

Menurut Gates dkk. dalam Djaali (2006:101), motivasi merupakan suatu kondisi fisiologis dan psikologis yang terdapat dalam diri seseorang yang mengatur tindakannya dengan cara tertentu. Lebih lanjut, Djaali (2006:101) mengutip Greenberg yang menyatakan bahwa motivasi adalah proses membangkitkan, mengarahkan dan memantapkan perilaku yang mengarah pada suatu tujuan. Hal senada ini dengan pendapat Mondy dan Premeaux yang dikutip oleh Kamars (2006:149) bahwa motivasi merupakan keinginan untuk meningkatkan usaha untuk mencapai tujuan-tujuan organisasi.

Dengan demikian, motivasi merupakan dorongan yang timbul dalam diri seseorang, 
baik yang disebabkan kondisi fisiologis maupun psikologis, secara sadar untuk melakukan suatu tindakan atau aktivitas tertentu guna mencapai suatu tujuan (kebutuhan).

Menurut Steer dan Porter, berbagai definisi motivasi yang ada memiliki persamaan yang mencirikan motivasi dalam diri seseorang, yaitu menggerakkan perilaku, mengarahkan perilaku dan menjaga perilaku. Ketiga hal tersebut merupakan fungsi dari motivasi yakni : 1) menggerakkan tingkah laku, artinya menimbulkan kekuatan pada diri seseorang yang dapat memimpinnya untuk bertindak dengan cara tertentu; 2) mengarahkan tingkah laku, artinya seseorang memiliki sesuatu orientasi tujuan atau dorongan. Dalam perkataan lain, setiap tingkah laku selalu diarahkan pada suatu sasaran atau objek tertentu; 3) menjaga tingkah laku, motivasi dalam diri seseorang dipengaruhi oleh kekuatan dalam dirinya dan lingkungan sekitarnya yang memberikan umpan balik untuk menguatkan intensitas dan arah dorongan-dorongan dan kekuatan individu atau sebaliknya.

Menurut Nashar (2004), motif merupakan segala sesuatu yang mendorong seseorang untuk bertindak melakukan sesuatu; sedangkan motivasi merupakan seluruh proses gerakan tersebut, termasuk situasi yang mendorong, dorongan yang timbul dalam diri individu, tingkah laku yang ditimbulkan oleh situasi tersebut dan tujuan dari perbuatan. Lebih lanjut, Nashar menjelaskan pengelompokkan motif menurut para pakar psikologi berdasarkan asalnya, yaitu : 1) motif biogenetis, yaitu motif yang berasal dari kebutuhankebutuhan organisme individu demi kelanjutan hidup secara biologis, misalnya : lapar, haus kebutuhan akan kegiatan, bernapas, seksualitas dan lainnya; 2) motif sosiogenetis, yaitu motif yang dipelajari individu dan berasal dari lingkungan kebudayaan tempatnya itu berada dan berkembang. Motif ini dipengaruhi oleh interaksi sosial individu dengan lingkungannya, misalnya: keinginan untuk mendengar musik barat, keinginan untuk bermain tenis dan lainnya; 3) motif teogenetis, yaitu motif yang berasal dari interaksi antara manusia dengan Tuhan seperti yang dalam ibadahnya, misalnya : keinginan untuk merealisasikan normanorma agama.

Dengan demikian, motivasi berhubungan erat dengan kebutuhan. Pada dasarnya motivasi sebagai penggerak perilaku dilatarbelakangi oleh pemenuhan 
Budaya Organisasi Sekolah dan Motivasi Berprestasi Isnaeni Wuryantini

kebutuhan dan juga untuk mencapai kebutuhan.

Maslow mengemukakan suatu teori motivasi yang disusun secara hirarkis sesuai kebutuhan manusia yang meliputi 5 tahap yaitu : 1) kebutuhan fisiologis, seperti: makanan, air, tidur, oksigen, seks dan lainnya; 2) kebutuhan keamanan, seperti: stabilitas, kemandirian, bebas dari rasa takut dan kegelisahan; 3) kebutuhan sosial, seperti: pertemanan, kasih sayang, hubungan dengan orang lain pada umumnya dan lainnya; 4) kebutuhan penghargaan, seperti: keinginan untuk dihargai, harga diri, wibawa, status dan lainnya; 5) aktualisasi diri, seperti: pengembangan diri yang berkelanjutan, perwujudan diri dan lainnya.

Houston mengutip Atkinson (1984) yang mengemukakan bahwa kebutuhan berprestasi merupakan salah satu kebutuhan manusia, yaitu dorongan untuk mengatasi hambatan, melatih kekuatan dan berusaha untuk melakukan suatu pekerjaan yang sulit dengan cara yang baik dan secepat mungkin. Menurut Atkinson, motivasi seseorang ditentukan oleh dua faktor, yaitu harapan terhadap suatu subjek dan nilai dari objek tersebut.

Berdasarkan pendapat Atkinson dan Feather yang dikutip dalam Houston, terdapat dua sistem motivasi yang saling bertolak belakang dalam setiap individu. Pertama, harapan untuk sukses yang memotivasi seseorang untuk meraih kesuksesan; kedua, takut akan kegagalan yang memotivasi seseorang untuk menghindari situasi prestasi. Harapan untuk sukses mendorong individu untuk meraih prestasi, tetapi pada saat yang bersamaan menjauhi prestasi karena menghindari kegagalan. Dalam hal ini, muncul kebutuhan yang memiliki nilai positif dan negatif sekaligus sehingga konflik ini bersifat sangat subjektif dan tidak selalu mencerminkan kenyataan yang ada.

Dengan demikian, dapat disimpulkan motivasi berprestasi adalah dorongan yang bersumber dari dalam diri manusia maupun yang bersumber dari luar dirinya yang dapat merangsang untuk berprestasi, yang ditandai dengan prestasi /kesuksesan yang dicapai dengan indikator adalah: 1) keinginan untuk unggul, 2) menerima tanggung jawab pribadi, 3) keinginan untuk mengambil resiko tingkat menengah dan umpan balik, 4) menyelesaikan tugas dengan baik, 5) menyukai tantangan serta 6) rasional dalam meraih keberhasilan.

\section{METODE}

Penelitian ini bertujuan untuk untuk a) mengetahui hubungan antara budaya organisasi sekolah dengan kinerja guru, b) 
mengetahui hubungan antara motivasi berprestasi dengan kinerja guru, c) mengetahui hubungan anara budaya organisasi sekolah dan motivasi berprestasi bersama-sama dengan kinerja guru

Penelitian ini dilaksanakan di Sekolah Dasar Negeri Gugus Adiarsa Karawang Barat. Sedangkan metode yang digunakan dalam penelitian ini adalah metode survey pendekatan kuantitatif.

Populasi dalam penelitian ini adalah guru-guru di SD yang berada di Gugus Adiarsa kecamatan Karawang Barat Kabupaten Karawang, dan sampel dari penelitian ini sebanyak 40 orang.

\section{HASIL}

Hasil pengujian normalitas galat taksiran regresi $\mathrm{Y}$ atas $\mathrm{X}_{1}$ dengan liliefors menunjukkan bahwa sebaran data penelitian berasal dari populasi berdistribusi normal, dengan $\mathrm{L}_{0}(0,121)<\mathrm{L}_{\text {tabel }}(0,140)$, sedangkan Hasil pengujian normalitas galat taksiran regresi $\quad \mathrm{Y}$ atas $\mathrm{X}_{2}$ dengan liliefors menunjukkan bahwa sebaran data penelitian berasal dari populasi berdistribusi normal, dengan $\mathrm{L}_{\mathrm{o}(0,129)}<\mathrm{L}_{\text {tabel }}(0,140)$.

Hasil pengujian Homogenitas Varians $Y$ atas $X_{1}$ dengan uji bartlett menunjukkan bahwa sebaran data penelitian berasal dari populasi homogen, dengan $\chi^{2}$ hitung $(8,13)<\chi^{2}$ tabel $(15,5)$. Sedangkan, hasil pengujian Homogenitas Varians $\mathrm{Y}$ atas $\mathrm{X}_{2}$ dengan uji bartlett menunjukkan bahwa sebaran data penelitian berasal dari populasi homogen, dengan $\chi^{2}$ hitung $(1,92)<\chi^{2}$ tabel $(11,1)$.

Hasil penelitian menemukan bahwa: pertama, terdapat hubungan positif yang berarti antara budaya sekolah dengan kinerja yang diperoleh koefisien korelasi 0,609, koefisien determinasi $37,09 \%$, thitung $(4,73)$ $>t_{\text {tabel }}(1,70)$, dan persamaan regresi $\hat{\mathrm{Y}}=$ $45,11+0,516 \mathrm{X}_{1}$.

Hasil analisis korelasi sederhana antara Budaya Organisasi Sekolah dengan Kinerja Guru diperoleh nilai koefisien korelasi ry 1 sebesar 0,609 . Nilai ini memberikan pengertian bahwa keterkaitan antara Budaya Organisasi Sekolah dengan Kinerja Guru adalah signifikan atau positif, artinya makin tinggi tingkat Budaya Organisasi Sekolah akan diikuti dengan naiknya Kinerja Guru tersebut.

Kedua, terdapat hubungan positif yang berarti antara gaya kepemimpinan dengan kinerja guru yang diperoleh koefisien korelasi 0,476, koefisien determinasi $22,66 \%$, $t_{\text {hitung }}(3,34)>t_{\text {tabel }}$ $(1,70)$, dan persamaan regresi $\hat{\mathrm{Y}}=57,98+$ $0,422 X_{2}$.

\section{PEMBAHASAN}

Hasil analisis korelasi sederhana antara Motivasi Berprestasi dengan Kinerja 
Budaya Organisasi Sekolah dan Motivasi Berprestasi Isnaeni Wuryantini

Guru diperoleh nilai koefisien korelasi $\mathrm{r}_{\mathrm{y} 2}$ sebesar 0,476. Nilai ini memberikan pengertian bahwa keterkaitan antara Motivasi Berprestasi dengan Kinerja Guru adalah signifikan atau positif, artinya makin tinggi tingkat Motivasi Berprestasi akan diikuti dengan naiknya Kinerja Guru tersebut.

Besarnya sumbangan atau kontribusi variabel Motivasi Berprestasi terhadap Kinerja Guru dapat diketahui dengan cara mengkuadratkan perolehan nilai koefisien korelasi sederhananya.

Hasil pengkuadratkan nilai koefisien korelasi sederhananya adalah sebesar 0,2266 . Secara statistik nilai ini memberikan pengertian bahwa kurang lebih 22,66 persen variasi Kinerja Guru ditentukan/dijelaskan oleh Motivasi Berprestasi dengan pola hubungan fungsionalnya seperti ditunjukan oleh persamaan regresi tersebut di atas.

ketiga, terdapat hubungan positif yang berarti antara budaya sekolah dan gaya kepemimpinan dengan kinerja guru, koefisien korelasinya 0,674 , koefisien determinasi $45,40 \%$, F Fitung $(15,40)>F_{\text {tabel }}$ $(5,25)$, dan persamaan regresi $\hat{Y}=27,91+$ $0,429 \mathrm{X}_{1}+0,272 \mathrm{X}_{2}$.

Hasil analisis korelasi ganda antara Budaya Organisasi Sekolah dan Motivasi Berprestasi dengan Kinerja Guru diperoleh nilai koefisien korelasi ganda sebesar $\mathrm{R}_{\mathrm{y} 12}$ sebesar 0,674. Nilai ini menunjukan bahwa keterkaitan antara Budaya Organisasi Sekolah dan Motivasi Berprestasi secara bersama-sama dengan Kinerja Guru baik. Dengan demikian berarti makin naiknya Budaya Organisasi Sekolah dan Motivasi Berprestasi, maka diikuti dengan tingginya Kinerja Guru.

Besarnya sumbangan atau konstribusi variabel Budaya Organisasi Sekolah dan Motivasi Berprestasi terhadap Kinerja Guru bersama-sama dapat diketahui melalui nilai koefisien determinasi $\mathrm{R}_{\mathrm{y} 12}^{2}$ sebesar 0,454. Hasil analisis tersebut menunjukan bahwa lebih kurang 45 persen variasi Kinerja Guru ditentukan / dijelaskan oleh Budaya Organisasi Sekolah dan Motivasi Berprestasi secara bersama-sama, seperti ditentukan oleh persamaan regresi tersebut di atas.

\section{SIMPULAN}

Kesimpulan dalam penelitian ini adalah Pertama, terdapat hubungan positif antara budaya organisasi sekolah dengan kinerja guru di SDN gugus Adiarsa Barat Kecamatan Karawang Barat Kabupaten Karawang. Kekuatan hubungannya ditunjukkan oleh koefisien korelasi 0,609 dan koefisien determinasi 0,3709 yang artinya $37,09 \%$ variasi kinerja guru di SDN 
gugus Adiarsa Barat Kecamatan Karawang Barat, dapat dijelaskan oleh variasi budaya organisasi sekolah. Dengan kata lain, makin kuat budaya organisasi sekolah maka makin tinggi kinerja guru.

Kedua, terdapat hubungan positif antara motivasi berprestasi dengan kinerja guru SDN gugus Adiarsa Barat Kecamatan Karawang Barat Kabupaten Karawang. Kekuatan hubungannya ditunjukkan oleh koefisien korelasi 0,476 dan koefisien determinasi 0,2266 yang artinya 22,66\% variasi kinerja guru di SDN gugus Adiarsa Barat Kecamatan Karawang Barat, dapat dijelaskan oleh variasi motivasi berprestasi. Dengan kata lain, maka semakin tinggi motivasi berprestasi maka makin tinggi kinerja guru.

Ketiga, terdapat hubungan positif antara budaya organisasi sekolah dan motivasi berprestasi secara bersama-sama dengan kinerja guru di SDN gugus Adiarsa Barat Kecamatan Karawang Barat, Kabupaten Karawang. Kekuatan hubungannya ditunjukkan oleh koefisien korelasi ganda 0,674 dan koefisien determinasi 0,454 yang artinya $45,40 \%$ variasi kinerja guru dapat dijelaskan secara bersama-sama oleh variasi budaya organisasi sekolah dan motivasi berprestasi. Dengan kata lain dapat dikemukakan makin kuat budaya organisasi sekolah dan motivasi berprestasi maka secara bersama-sama makin tinggi pula kinerja guru.

\section{DAFTAR RUJUKAN}

Colquith, Jason A., Jeffrey A. LePine, and Michael J. Wesson, 2009. Organizational Behavior: Improving Performance and Committment in the Work Place, New York, McGraw-Hill/Irwin.

Djaali, 2006. Psikologi Pendidikan, Jakarta : Bumi Aksara.

Fred Luthans, 2008. Organizational Behavior, New York, McGraw-Hill Companies, Inc.

Gibson, Ivancevich, Donnelly, Konopaske, 2006. Organizations Behavior, Structure, Process, New York, McGraw-Hill Companies, Inc.

Gulton Maurice and Brian Simon, 1994. Progress and Performance in The Primary Class Room, London, Prentice-Hall.

J. Winardi, 2007. Motivasi dan Pemotivasian Dalam Manajemen, Jakarta, PT. RajaGrafindo Persada.

King Patricia, 1993. Performance Planning and Appraisal: A Hall to Book for Manager, New York, McGraw-Hill.

Kreitner, Robert and Angelo Kinicki, 2008. Organizational Behavior, Homewood, Richard Irwin.

M. Dachnel Kamars, 2006. Administrasi Pendidikan : Teori dan Praktek, 
Budaya Organisasi Sekolah dan Motivasi Berprestasi Isnaeni Wuryantini

Padang : Universitas Putra Indonesia Press.

Malayu S.P. Hasibuan, 2007. Organisasi dan Motivasi: Dasar Peningkatan Produktivitas, Jakarta : Bumi Aksara.

McShane, Steven L. and Mary Ann Von Glinov, 2008. Organizational Behavior, New York, McGraw-Hill Companies, Inc.

Newstrom, John W. and Keith Davis, 2002. Organizational Behavior : Human Behavior at Work, New York, McGraw-Hill Higher Education.

Nashar, 2004. Peranan Motivasi dan Kemampuan Awal Dalam Kegiatan Pembelajaran, Jakarta: Delia Press.

Richard M. Steer and Lyman W. Porter, 1994. Motivation and Work Behavior, Singapore : McGraw-Hill Inc.

Schein, Edgar, 2004. Organizational Culture and Leadership, San Fransisco, John Wiley and Son.

Stephen P. Robbins, 2008. Organizational Behavior, New Jersey, Pearson International Edition.

Stephen P. Robbins, Mary Coulter, 2003. Management, Australia, Pearson International Edition.

Stephen P. Robbins, Timothy A. 2007. Judge, Organizational Behavior, New Jersey, Pearson International Edition.

Stephen P. Robbins, Timothy A. Judge, 2009. Organizational Behavior,
New Jersey, Pearson International Edition.

Vroom Victor H., 2009. Work and Motivation, Phisburgh, John Willey $\&$ Sons Inc.

Walker James W. 2000. Human Resource Strategy, New York. McGraw-Hill. 